Board of Governors of the Federal Reserve System

International Finance Discussion Papers

Number 542

February 1996

\title{
PRECAUTIONARY PORTFOLIO BEHAVIOR FROM A LIFE-CYCLE PERSPECTIVE
}

Carol C. Bertaut and Michael Haliassos

Note: International Finance Discussion Papers are preliminary materials circulated to stimulate discussion and critical comment. References in publications to International Finance Discussion Papers (other than an acknowledgement that the writer has had access to unpublished material) should be cleared with the author or authors. 


\begin{abstract}
The literature on asset accumulation by households draws a sharp distinction between "short-run" precautionary motives to buffer annual consumption from annual labor income shocks, and "long-run" life cycle considerations under labor income certainty. However, empirical estimates of the persistence of shocks to annual incomes imply that households are subject to considerable career uncertainty. We study long-run precautionary motives for life-cycle wealth accumulation and portfolio choice. We compute optimal portfolios under three sources of uncertainty (stock returns, incomes, and lifespan), and explore the separate contributions of several key factors for mean and median asset holdings, including education, risk aversion, household heterogeneity, utility from bequests, time preference, and variance and serial correlation of income shocks. Numerical solutions for households in three education groups are compared with data from the most recent and comprehensive source, the 1992 Survey of Consumer Finances.
\end{abstract}




\title{
PRECAUTIONARY PORTFOLIO BEHAVIOR FROM A LIFE-CYCLE PERSPECTIVE
}

\author{
Carol C. Bertaut and Michael Haliassos ${ }^{1}$
}

\section{Introduction}

Traditional models of life-cycle motives for wealth accumulation abstract from nondiversifiable labor income risk faced by households, and have tended to underpredict aggregate wealth in the United States ${ }^{1}$ and to overpredict "typical" behavior as captured by median wealth. ${ }^{2}$ Following Leland (1968) and Sandmo (1970), Kimball (1990) showed that such risk necessitates additional ("precautionary") wealth holding to buffer consumption from income shocks when utility exhibits "prudence" in the form of a positive third derivative.

Models of precautionary motives which employ the commonly used constant-relative-riskaversion (CRRA) utility function require numerical solutions. ${ }^{3}$ Computational studies by Hubbard and Judd (1987), Skinner (1988), and Zeldes (1989) among others, have abstracted from portfolio choice and shown that if the objective of households is to buffer annual consumption from shocks to annual income, substantial wealth holding is required. In order to reduce unrealistically high predicted levels of wealth to observed levels, Deaton (1991) and Carroll (1992) proposed models

1 The authors are respectively: Economist, Division of International Finance, Board of Governors of the Federal Reserve System; and Assistant Professor, Department of Economics, University of Cyprus. We are grateful to two referees and to Stavros Zenios for constructive comments on an earlier draft. Zoe Chimonidou and Matthew Field provided excellent research assistance. We would like to thank, without implicating, Michael Brennan, Steffen Pischke, Nikitas Pittis, Aris Spanos, and Martha Starr-McCluer for helpful discussions. Haliassos' research was supported by a grant from the Research Committee of the University of Cyprus. The first draft of this paper was written on two sides of the Atlantic without a single fax or telephone call, thanks to the availability of Internet. This paper represents the views of the authors and should not be interpreted as reflecting those of the Board of Governors of the Federal Reserve System or other members of its staff. 
which postulate considerable impatience in the form of a high rate of time preference. Hubbard et. al. (1995) introduce instead institutional factors such as asset-based, means-tested benefits to account for limited wealth holding by those with less than high school education. Hubbard, et.al. (1994) approximate observed wealth levels without assuming impatience by building a ninetyperiod model which incorporates not only income risk, but also uncertainty as to medical expenditures and lifespan. The few existing econometric tests of precautionary motives yield mixed results. ${ }^{4}$

This paper explores the implications of an alternative assumption about household lifecycle objectives, and extends the analysis to discuss not only wealth holding but also the portfolio choice between riskless and risky assets. Empirical evidence on the frequency and extent of portfolio adjustments by households is hard to reconcile with the assumption that they continuously rebalance their portfolios to buffer annual consumption from shocks to annual incomes. ${ }^{5}$ We postulate that households choose portfolios so as to buffer consumption over longer periods from shocks to income over correspondingly long horizons, and we study the effects of such long-run precautionary motives on portfolio choice by young households. ${ }^{6}$ As seen below, the observed persistence of shocks to annual incomes implies that such households are subject to considerable "career uncertainty", and this is likely to have quantitatively important influence on their choice of portfolios for retirement and bequests. ${ }^{7}$

Although households probably decide part of riskless asset holdings (e.g., checking and savings accounts) with other, shorter-run motives in mind (e.g., transactions motives), we investigate what proportion of their risky and riskless asset holding can be accounted for by this life-cycle precautionary motive alone. For this purpose, predictions from different variants of the 
model are compared to the most recent and comprehensive data on household portfolios, namely the 1992 Survey of Consumer Finances ( $S C F$ ). The long-run nature of our model allows us to compute optimal portfolios under three sources of uncertainty (stock returns, incomes, and lifespan), to consider both representative agent models and effects of population heterogeneity, and to explore the separate contributions of several factors, including education, risk aversion, time preference, variance and serial correlation of income shocks, and utility from bequests. Predictions are compared to data on mean and median portfolios, by education group. This gives us two important perspectives on predictive performance in view of the limited incidence of stockholding analyzed in Haliassos and Bertaut (1995).

Section II describes mean and median portfolios by age and education group, using the 1992 SCF. Section III describes two variants of the basic expected-utility model. Section IV first describes calibration of income processes and two departures from certainty models. It then traces the effects of differences in the income processes, starting with the process relevant for the least educated households and gradually transforming it into that applicable to their most educated counterparts. Section V compares empirical wealth-to-income and stock-to-income ratios with those implied by the models. Section VI concludes. The Data Appendix gives definitions of variables and $S C F$ codes.

\section{Portfolio Holdings of U.S. Households}

We divide total household financial net worth from the 1992 SCF into risky "stocks" and "riskless assets". For most of our discussion, we include under stocks shares of publicly traded stocks, shares in stock mutual funds, and other "directly held" stocks in IRAs and Keogh plans. 
We also consider a broader definition that includes stocks held in trusts, managed investment accounts, and defined-contribution pension plans. Our riskless assets include checking, saving, money market, and call accounts, CDs, saving and other bonds, and the cash value of life insurance. We subtract from riskless assets credit card balances, consumer loans, and other non-real estate loans. When we consider our broader definition of stocks, we also include in financial net worth assets in managed accounts and defined contribution pension plans. Labor income includes wage and salary income, income derived from a professional business or practice, unemployment and worker's compensation payments, and income from Social Security and other pensions. We estimated after-tax labor income for non-retirement sources from information on each household's tax filing status and adjusted gross income (see Appendix 1).

Table 1 shows mean and median holdings of directly held stocks and total financial net worth by education and age. For all age groups, both mean holdings of stocks (col. 1) and mean financial net worth (col. 2) increase with education. For example, households aged 30-39 with less than a high school education have a mean stock portfolio of $\$ 100$, about 8 percent of their total financial net worth (col. 3). For those the same age and a high school degree, the mean stock portfolio increases to about $\$ 1,500$, or 12 percent of total financial net worth, and to nearly $\$ 20,000$, or 56 percent, for those with a college degree. Among older households without a college degree, the share of stocks in financial net worth is larger, reaching about half the portfolio of those at age 40-59. In contrast, stocks comprise more than half the portfolio of young college graduates. Although the level of stocks is higher among older college-educated households, the share is lower. ${ }^{8}$ 
In large part, mean stock portfolios for all education levels and ages reflect holdings by each group as a whole, but not typical behavior. Only 7 percent of households with less than a high school education actually hold stocks; this fraction increases to 23 percent for households who have completed high school, and to 48 percent for those with a college degree. Columns 4 , 5 and 6 show median stock portfolios, financial net worth, and stock shares. For households with less than a college education, the median portfolio contains no stocks, nor does the portfolio of the median young, college-educated household. For older college-educated households, the median portfolio share in stocks is larger, reaching 11 percent for those aged $60-69$, and then drops to about 1 percent.

Table 2 gives the same breakdown of information as Table 1, but uses the broader definition of stocks and total financial net worth that includes indirectly held assets. This increases both the mean amount and portfolio share of stocks for almost all age and education levels. For households aged 30-39 without a college degree, stockholding now comprises between 20 and 30 percent of the portfolio, and almost 60 percent for young college-educated households. However, adding indirectly held stocks makes little difference to the median portfolio unless the household has a college education. As in Table 1, the median portfolio still contains stocks only for these households, and the share of their median portfolio in stocks is considerably larger, reaching over 30 percent for those aged 50 to 69.

\section{The Basic Models}

We solve numerous variants of two basic models. For each calibrated model, we program analytically derived first-order conditions, identities, and constraints as a system of nonlinear 
equations, and compute solutions for all endogenous variables using Matlab's modified Newton method with line search to ensure global convergence.

Suppose that a household Iives for three twenty-year periods, and receives exogenous real income from employment, unemployment, or retirement, $Y_{t}$, in period $t$. The household is subject to three sources of uncertainty: income risk, stock returns, and lifespan uncertainty. We follow the standard practice in the precautionary saving literature of assuming zero correlation between nondiversifiable income risk and asset returns. At the end of each of the first two periods, after ail current variables are realized, the household chooses its holdings of stocks and riskless assets for the next period (and implicitly consumption) with a view to their cumulative returns and to present values of incomes over the twenty years. The algebraic sum of households' stock and bond holdings is defined as their financial net worth ("wealth"). In the third period, households repay any accumulated debts. In the model without bequests, they consume the remainder of their labor and interest income and asset holdings. Formally, the household solves:

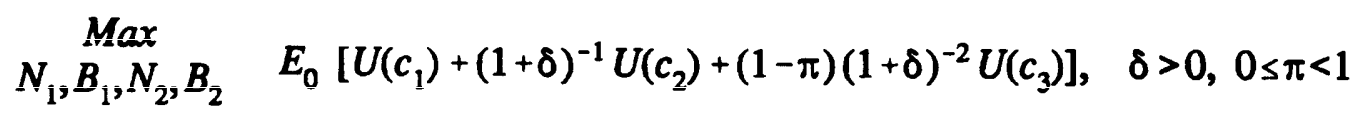

where $N_{t}$ denotes number of stocks held between periods $t$ and $t+l, B$, nominal riskless holdings, $\pi$ is the probability of premature death, and $\delta$ is the rate of time preference. The utility function is of the form

$$
U\left(c_{t}\right)=\frac{c_{t}^{1-\gamma}-1}{1-\gamma}
$$

where $\gamma$ is the (constant) degree of relative risk aversion. The constraints are: 


$$
\begin{gathered}
c_{1}=Y_{1}-N_{1} \frac{S_{1}}{P_{1}}-\frac{B_{1}}{P_{1}} \\
c_{2}=Y_{2}+\left(N_{1} d_{2}+\frac{B_{1} I_{2}}{P_{2}}\right)\left(1-t_{b}\right)+\left(N_{1}-N_{2}\right) \frac{S_{2}}{P_{2}}+\frac{B_{1}-B_{2}}{P_{2}} \\
c_{3}=Y_{3}+N_{\overline{2}}\left[\frac{S_{3}}{P_{3}}+d_{3}\left(1-t_{b}\right)\right]+\frac{B_{2}\left[1+I_{3}\left(1-t_{b}\right)\right]}{P_{3}} \\
c_{t} \geq 0 \quad \forall t .
\end{gathered}
$$

$S$ is the nominal stock price, $d$ real dividends per share, $I$ the nominal rate of interest on the riskless asset, $P$ the price of the good, and $t_{b}$ the tax rate on interest and dividend income. We abstract from capital gains taxation for simplicity. ${ }^{9}$ Short sales constraints on stocks are never binding in this model. If households need to borrow, they will do so at the (lower) riskless rate rather than at the risky rate which also has higher expected value.

The absence of borrowing constraints, in the form of either quantity constraints or of a wedge between borrowing and lending rates is a standard assumption in life-cycle models, which is still debated in the literature. It is employed here to investigate how far a standard life cycle model can go in accounting for portfolios when only the assumptions of continuous rebalancing and no income risk are relaxed. Nevertheless, households do not engage in unbounded borrowing. As also noted by Aiyagari (1994), constraint (6) ensures finiteness of net worth, since consumption must occur even in adverse labor income and/or stock return states. Under CRRA utility, such constraints are superfluous, since $U^{\prime}(0)$ is unbounded, ensuring positive optimal consumption. Moreover, finite net worth is not associated with infinite borrowing combined with 
infinite stockholding. Such a combination would involve bankruptcy in bad stock return states and would not be chosen by CRRA households.

In the second model variant, we introduce utility from bequests, $G$. According to the 1992 SCF, $20.8 \%$ of households received or expected to receive a sizeable bequest, while $49.5 \%$ said they planned to leave a bequest. ${ }^{10}$ Third-period utility becomes:

$$
U\left(c_{3}, G\right)=(1-\lambda) \frac{c_{3}^{1-\gamma}-1}{1-\gamma}+\lambda \frac{G^{1-\gamma}-1}{1-\gamma}
$$

Bequests are uncertain because of income and stockholding risk. The parameter $\lambda$ controls the choice between last-period consumption and bequest. If households care about bequests $(\lambda>0)$, they behave so as to leave a bequest in any state of the world. The institutional requirement of nonnegative intentional bequests is met endogenously. Although we impose unconditionally positive bequests for $\lambda>0$, we understate bequest motives by eliminating the probability of premature death and household concern over the size of accidental bequests. We found that predictions move closer to the data, without the heavy informational requirements usually imposed by infinite-horizon dynastic models. ${ }^{11}$

In the benchmark model without bequests, risk aversion is set at 3 , as is usual in this literature, the probability of premature death at zero, and the rate of time preference at $3.13 \%$, equal to the mean riskless rate estimated by Siegel (1992) over the period $1800-1990^{12}$ and close to the value of $3 \%$ assumed in Hubbard et.al. $(1994,1995)$. Sensitivity of solutions to the values of these parameters is examined below.

Annual stock returns can take a high or low value with equal probability, matching the first two moments of the long-run empirical return distribution estimated by Mehra and Prescott 
(1985). ${ }^{13}$ Following Haliassos and Lyon (1994), we compute the expected value and the standard deviation of 20 -year holding returns using the binomial process for annual returns. Finally, we choose a "high" and a "low" 20-year return that match these two moments. Expected dividend yields are set to about half the expected total pre-tax return on equity, which is consistent with the historical findings of Schwert (1990). ${ }^{14}$ The twenty-year riskless rate is the Mehra-Prescott mean annual riskless rate compounded over twenty years. We consider the case of no correlation between income and stock returns, which gives us four second-period states. ${ }^{15}$ In the absence of retirement income risk, there are eight third-period states (provided that the household survives).

\section{Precautionary Motives from a Longer-run Perspective}

\section{IV.1 Calibration of Income Processes}

Households choose portfolios to buffer longer-run measures of consumption from shocks to the present values of their income over twenty-year periods, computed using the riskless rate at which they are able to borrow and lend. In the first version of the model, the representative household is faced with no income uncertainty and is guaranteed the average population income at each age. ${ }^{16}$ In the second, income is uncertain in the second period, but its expected value equals the level guaranteed in the certainty version. In the third, we consider a population of heterogeneous households generated by different income shock realizations during the first period. Our procedure ensures that average household incomes are equal to those guaranteed to the representative household under certainty and to their expected values under uncertainty. ${ }^{17} \mathrm{We}$ account for serial correlation of annual income shocks not only within the second period of life, 
but also across the first and the second period. The second and third versions are solved both without and with bequest motives.

We distinguish between three groups based on education of the household head: (i) less than high school education (LTHS), (ii) high-school education but no college degree (HS), and (iii) college degree or more (COL). This classification is usually motivated by similarities of long-run income prospects (e.g., Hubbard et.al., 1994; 1995), but it may also be relevant for the degree of financial sophistication. In the versions with income risk, annual incomes for each education group $i$ and year $t$ in a twenty-year period of life are given by

$$
Y_{i t}=Y_{i t}^{*} U_{i t} V_{i t}
$$

where $Y^{*}$ is the corresponding income value in the certainty version of the model. The logarithms of shocks $U$ and $V$, denoted by lower-case letters, are assumed to follow the processes estimated by Hubbard et. al. (1994). While the logarithm of shock $U$ exhibits considerable persistence for all education groups, the variances of transitory and persistent shocks decline with education:

$$
\begin{aligned}
& u_{\text {LTHS }, t}=0.955 u_{\text {LTHS, },-1}+e_{\text {LTHS,, }} \quad e_{\text {LTHS,t }} \sim \text { i.i.d. } N(0,0.033), \quad v_{L T H S, t} \sim N(0,0.04) \\
& u_{H S, t}=0.946 u_{H S, t-1}+e_{H S, t} \quad e_{H S, t}-\text { i.i.d. } N(0,0.025), \quad v_{H S, t} \sim N(0,0.021) \\
& u_{\text {COL, }}=0.955 u_{\text {COL, } t-1}+e_{C O L, t}, \quad e_{C O L, t} \sim \text { i.i.d. } N(0,0.016), \quad v_{C O L, t} \sim N(0,0.014)
\end{aligned}
$$

\section{IV.I.I Representative-household Model with Income Risk}

In this version, first-period income is set equal to the average income for the relevant ageeducation group. By construction, multiplicative income shocks are equal to unity, and serial correlation in the logarithms does not imply second-period effects of first-period shocks. 
We derive the implications of annual income shocks for the present value of incomes over the second twenty-year period. We first draw randomly 200,000 realizations of shocks $e$ and $v$ for each education group from the corresponding lognormal distributions in (9), and use them to construct 10,000 draws of 20 -year income sequences. Using the resulting 10,000 realizations of present values, we compute the expected present value and its standard deviation by category. High and low income values are set to mean plus or minus one standard deviation respectively.

Introduction of lognormally distributed income shocks increases mean incomes above their value under certainty. ${ }^{18}$ In order to eliminate this side-effect, annual income values used above are adjusted as follows:

$$
Y_{i t}=\exp \left[\ln Y_{i t}^{*}-0.5\left(\sigma_{i u, t}^{2}+\sigma_{i v}^{2}\right)\right]
$$

where $Y^{*}{ }_{i t}$ is the income value under certainty for education group $i$ in year $t$, and $\sigma_{i u, t}^{2}$ and $\sigma_{i v}^{2}$ are the unconditional variances of the logarithms of persistent and transitory shocks respectively. ${ }^{19}$ Dropping the education group subscript, their sum in the first year of the period is $\sigma_{\epsilon}^{2}+\sigma_{v}^{2}$. Its value in subsequent years can be obtained using the recursive formula

$$
\sigma_{u, t}^{2}=\sigma_{u, t-1}^{2}+\rho^{2(t-1)} \sigma_{\epsilon}^{2}
$$

Comparison of good and bad income states suggests that shocks to annual incomes generate substantial uncertainty for a representative household even with regard to twenty-year present values. Since we are used to thinking about annual incomes rather than present values, Table 3 presents "equivalent" annual incomes which would yield the corresponding twenty-year present value if received each year. This redefinition of units is useful for interpretation and 
harmless to results. It has been shown that scaling up or down incomes in all states of the world and time periods results in consumption levels and asset holdings which are also scaled by the same factor (Bar-Ilan, 1991).

Table 3 shows that all education groups experience their peak incomes in the absence of shocks, or their peak expected incomes in the presence of shocks, during the second period of life. For college graduates, incomes in the third period are higher than in the first, though this is not true for the other two groups. Those with less than high school education, unlike others, are faced with a prospect of lower income than in the first period of life.

\section{IV.1.2 From a Representative Household to a Population of Households}

Households with the same education and income process generally experience different income realizations. Nondiversifiable income risk generates a population of heterogeneous households by the end of the first period, and their average (median) asset holdings need not be the same as those of a representative household which earns average (median) income. In this set of calibrations, we explore the importance of any such differences.

Following the above procedure, we compute 10,000 present value realizations for the first period of life and break them up into ten categories (with equal ranges). We economize on computational effort by solving ten problems, where first-period income is set equal to the average for that income category. Predictions for each education group are computed by weighting predictions for each category by its relative frequency. The corresponding weighted average of incomes is equal to average income among all 10,000 households, to the income of the representative agent in version 2 , and to that under certainty in version 1. 
The major computational economy comes in calibrating the risk households face conditional on first-period income and in view of serially correlated shocks. Instead of generating 10,000 present value realizations for each of 10,000 households, we do so for each of 10 income categories. Suppose there are 50 households in a category. By replicating each household two hundred times, we come up with 10,000 households while preserving the relative frequency of incomes within the category. Randomly assigning shocks to each, allowing for serial correlation, and correcting for unwanted mean effects, we generate 10,000 present value realizations. ${ }^{20}$ Their mean and variance describe second-period income uncertainty, conditional on being in that category of first-period income.

\section{2 Portfolio Effects of Differences in Income Processes}

Table 3 and equation (9) show that income processes differ across education groups both in terms of no-shock levels and in terms of stochastic properties. In this subsection, we illustrate the effects of such differences in the context of the benchmark model with income risk but no bequests. Comparisons are not influenced by differences in random draws, since the same draws of $e$ and $v$ are used as in the original calibration. The direction and relative importance of effects are shown in Table 4 (cols. 4-6).

We first solve the model using the income process for households with less than high school education (step 1). In step 2, we use no-shock income levels of high-school graduates, but shocks applying to the least educated households. In step 3, we set the variance of persistent shocks to that of high-school graduates. In step 4, serial correlation is also adjusted. In step 5 the variance of transitory shocks is adjusted to replicate the process for high-school graduates. The 
sequence is repeated for transforming high-school graduates to college graduates, with one additional step. Step 7 changes the tax rate on dividend and interest income, $t_{h}$, from $15 \%$ to $30 \%$, the rate assumed to apply to college-educated househoids.

College no-shock income profiles have the largest effects, substantially encouraging borrowing and stockholding. Smaller variance of the (logarithm of) persistent shocks, $e_{t}$, (step 3 or 8) encourages borrowing, lowers $W / Y$, but also increases stockholding. This is a generalization of a finding by Kimball (1993) in the context of an atemporal model: a meanpreserving reduction in the size of background income risk makes risky assets more desirable because of the property of CRRA utility functions termed "standard risk aversion". However, the reduction in variance of temporary shocks, $v_{n}$, associated with a higher education level (step 5 or 10) has negligible portfolio effects. A reduction in serial correlation (step 4), encourages both borrowing and stockholding, with a negative overall effect on W/Y. Step 9, which increases serial correlation, has the opposite effects. Finally, an increase in tax rates (step 7) reduces wealth by encouraging borrowing, while also encouraging stockholding. Increased borrowing arises because interest taxation is proportional, resulting in larger tax "refunds" from interest payments on loans when tax rates on interest increase. The positive effect on stockholding is attributable to the reduction in riskiness of after-tax stock returns when tax rates are higher. ${ }^{21}$

\section{3 Comparison of Model Predictions}

Table 5 reports predicted ratios of average (median) wealth to average (median) income, for a subset of the models we have solved. Table 6 reports the corresponding ratios for stocks. Solutions for various degrees of risk aversion within the range of 2 to 10 , which Mehra and 
Prescott consider appropriate for representative agent models, are presented. Regardless of education, higher risk aversion lowers optimal stockholding (S/Y), but discourages borrowing by more, lowering current consumption to boost consumption in bad states. This results in higher wealth-to-income ratios (Fig. 1).

The representative agent model which ignores income risk predicts positive stock to income ratios but also substantial borrowing which actually makes financial net worth negative (col. 1). If age-earnings profiles are guaranteed to the representative household in each education group and there are no bequest motives, then it should undertake considerable borrowing in the middle of its working life to finance consumption and to purchase stocks.

In column 2 , income shocks are allowed only in the second period. ${ }^{22}$ The representativeagent nature of the model underestimates the importance of income risk, since shocks during the first period are not incorporated to differentiate households. Wealth to income ratios increase by 8 to 16 percentage points (pp), and the magnitude of the effect increases with risk aversion. Stock to income ratios are somewhat reduced because of background income risk.

In unreported calibrations, we varied the rate of time preference from $.1 \%$ to $7.5 \%$. Reduced concern about the future makes equity premia less important and discourages investment in stock. Current consumption increases and is financed both through increased borrowing and reduced stockholding. The schedules for $\mathrm{S} / \mathrm{Y}, \mathrm{B} / \mathrm{Y}$, and $\mathrm{W} / \mathrm{Y}$ against time preference are essentially linear, negatively sloped, and steeper for college-educated households. The prediction that it is optimal for all groups to be net borrowers is robust to time preference. We also introduced perceived probabilities of premature death at the end of the second period ranging from 5 to 75 percent. Optimal wealth-to-income ratios are reduced. Since households are less 
likely to survive to retirement, when they would consume and leave bequests, they find equity premia less appealing and borrow to boost current consumption. ${ }^{23}$

In column 3, we allow for first-period income shocks and for persistence of the serially correlated shocks into the second period. We now average across solutions for heterogeneous households based on first period incomes. Wealth to income ratios are further increased by 3 or $4 \mathrm{pp}$ in all education groups. Stock to income ratios are either unaffected or further reduced by about 1 to 2 pp.

Substantial effects are obtained by introducing bequest motives in a representative agent model (col. 4), more so for larger degrees of risk aversion and higher education levels. For a high school dropout with risk aversion of 2 , the wealth to income ratio rises above the population model without bequests by $5 \mathrm{pp}$ and above the representative agent model with income risk by $9 \mathrm{pp}$. At the opposite end, the corresponding changes for college graduates with risk aversion of 10 are 24 and $28 \mathrm{pp}$ respectively. Stock to income ratios increase, as households accumulate to provide for future consumption and bequests, essentially returning to levels implied by the certainty model. Generalization to a population model with bequests (col. 5) raises wealth to income ratios by a further 3 to $4 \mathrm{pp}$, while lowering stock to income ratios by 1 to $2 \mathrm{pp}$.

Population models allow computation of predicted ratios of median wealth and median stocks to median incomes. Again, introduction of bequest motives has substantial positive effects on the former, especially for college graduates, which range from 9 to 30 pp (columns 6 and 7). Effects on the latter are also positive but small.

All in all, the cumulative effect of allowing for long-run income risk, bequests, and population heterogeneity is to increase predicted ratios of average wealth to average income by 
20 to $44 \mathrm{pp}$, while reducing stock to income ratios by between 1 and $7 \mathrm{pp}$ relative to the representative agent model with no income risk. For each education level, increases in $\mathrm{W} / \mathrm{Y}$ are larger and reductions in $\mathrm{S} / \mathrm{Y}$ smaller the higher the degree of risk aversion. For any risk aversion, effects on $\mathrm{W} / \mathrm{Y}$ are largest for college graduates and smallest for high school graduates. Effects on optimal S/Y are somewhat more pronounced among high school dropouts than among others.

\section{A Comparison of Observed Portfolios with Model Predictions}

Since we are focusing on longer-run motives, our objective is not to match model predictions to the data, but to examine the extent to which the level and composition of asset holdings depart from long-run objectives incorporated in the models. This also defines the direction in which short-run (e.g., transactions) and other motives must operate if they are to account for actual portfolios.

We focus on the extent to which the model accounts for (i) average behavior, (ii) typical behavior, and (iii) household heterogeneity in the age cell of 30 to 39 years for each education group. For (i), which is our main focus, the metric used is the ratio of average wealth (or stocks) to average labor income in the cell, which is equivalent to the ratio of total wealth (or stocks) to total income. ${ }^{24}$ Since asset holdings are often skewed, medians represent typical behavior more closely than means. So, for (ii) we use ratios of medians. An interesting puzzle in (iii) is the limited incidence of stockholding among US households. We have addressed this issue extensively in Haliassos and Bertaut (1995). The discussion here explores instead whether longrun models are versatile enough to generate the variety of nonzero portfolio combinations 
observed in household data (e.g., negative net worth combined with stockholding, or positive holdings of both assets, etc.).

For comparison with model predictions, cols. 1 and 2 of Table 7 give U.S. household mean financial net worth and mean stocks scaled by mean after-tax labor income (W/Y and $S / Y$ ), by age and education level. Columns 5 and 6 use the broader definitions of stocks and financial net worth. For all education levels, W/Y (cols. 1 and 5) is higher among older groups. For any given age, the ratio increases with education. For older households with at least a high school education, mean financial net worth is several times annual labor income. The ratios of $S / Y$ (cols. 2 and 6) also show considerable variation by education level. For most households with less than high school education, the mean level of stocks never amounts to more than 40 percent of labor income. S/Y is especially small for young households, reflecting the low level of stocks held. Households with high school or college education have a substantially higher S/Y ratio. Older households in these education groups hold a mean stock portfolio that is greater than their mean after-tax labor income. Including indirectly held stocks increases this ratio considerably for these households. Columns $3,4,7$, and 8 show ratios of median wealth or stocks to median incomes.

\section{Average Household Behavior}

Table 6 shows that for the two more educated categories, models which recognize life cycle precautionary motives yield ratios of stocks to income within the bands of data averages in Table 7. In the case of college graduates, risk aversion of 4 generates ratios between .35 and .45 when long-run uncertainty is recognized. For high school graduates, the empirical band is between .04 and .13 , and risk aversion of 7 generates such ratios in the modeis with uncertainty. 
This ranking in terms of risk aversion is consistent with responses on attitudes towards financial risk taking in the Survey which suggest that risk aversion declines with education (Table 8). Thus, models which postulate that households decide asset holdings with a view to buffering consumption from shocks to longer run income measures can reasonably account for average stockholding among the two more educated categories.

With regard to riskless assets, Tables 5 and 7 suggest that life-cycle precautionary motives, especially in conjunction with heterogeneity and bequest motives, can explain a significant part of the discrepancy between a life cycle model under certainty and empirical observations. However, part of riskless holdings by the two more educated groups are attributable to shorter-run or other motives. For high school graduates, the long-run models account for about one third of the wealth to income ratio. For college graduates, they imply that long-run motives alone and the nature of the income process would justify substantial borrowing, to the point of making financial net worth negative early in life.

Households with less than high school education differ. As comparison of Tables 5 and 7 suggests, their entire wealth to income ratio can be accounted for by the model with bequests and population heterogeneity at degree of risk aversion of 6 . However, their limited average stockholding cannot be explained for degrees of risk aversion between 2 and 12. Had we only looked at aggregate wealth, we would have concluded that the model matches their behavior exactly. This raises some interesting research questions regarding the predictive ability of other models which approximate wealth to income ratios but have not yet been extended to analysis of portfolio composition. 
Limited average stockholding in this education group is primarily attributable to the very small proportion of stockholders, both in absolute terms and by comparison to other groups. This is true not only in 1992, but also in 1984 PSID (Mankiw and Zeldes, 1991) and in 1983 SCF data (Haliassos and Bertaut, 1995). Haliassos and Bertaut showed that an expected-utility life cycle model without frictions (such as information costs or other sources of inertia) has trouble accounting for the limited incidence of stockholding. For low-education households, among whom stockholding incidence is minimal, this inherent limitation of the model distorts its prediction of average behavior, but not so for the other two categories.

\section{b. Typical Household Behavior and Household Heterogeneity}

Median direct stockholding is zero for each age-education group, except for college graduates over 40 . The finding that not only the incidence but also the average level of stockholding by high school dropouts is below predictions gives further support to the view that inertia, information, and sophistication are important factors for stockholding behavior.

If we focus on median wealth and its relation to median income, we compare observed ratios (Table 7, cols. 3 and 7) to those predicted by our population models (Table 5, cols. 6 and 7). Our model with bequests explains about one half of the empirical ratio for high school dropouts if we constrain ourselves not to consider risk aversion in excess of 10. For high school graduates, the same model can fully account for the observed ratio for risk aversion of 9 . However, the model yields consistently negative ratios for college graduates.

Although the typical (median) young household in the $S C F$ has positive riskless holdings and no stocks, there is considerable heterogeneity within each age-education group. In all three 
education groups, some young households (between 10 and 25 percent) have negative financial net worth, and a fraction of these are stockholders under the broader asset definitions. The proportion of these stockholder households who borrow is slightly higher for college-educated households. Our population models yield (unreported) solutions for various categories consistent with the existence of such households and with their increased importance among households with college education. Even for college-educated households, for whom our models uniformly predict negative ratios of average wealth to average income, the population model with bequests generates positive wealth-to-income ratios for some income categories and degrees of risk aversion. The higher the degree of risk aversion, the larger is the number of such categories. Thus, there is nothing in these models to prevent them from predicting the variety of nonzero portfolio combinations observed in the data. Matching relative frequencies may require more elaborate models and/or greater precision in defining first-period income categories. We intend to pursue this in future research.

\section{Concluding Remarks}

We explore the implications of a bold assumption about household portfolio behavior, namely that household wealth and portfolios around the middle of working life are chosen so as to buffer consumption over long periods of time from shocks to corresponding long-run income measures, i.e. "career uncertainty". Using numerical computation, we show how the predictions of an otherwise standard life-cycle model with no income risk can be brought closer to empirical observations by (i) incorporating long-run income risk, (ii) introducing bequest motives, and (iii) 
abandoning the representative-agent assumption to consider the effects of income shocks in creating a population of heterogeneous households.

We distinguish between three education groups and use empirically estimated income processes for each to calibrate the extent of career uncertainty it faces. Data on portfolios come from the most comprehensive and most recent source, the 1992 Survey of Consumer Finances. The simple career risk model can account for all of stockholding among the two more educated income groups at plausible degrees of risk aversion and other parameter values, but leaves part of riskless asset holding to be explained with reference to other considerations. It can also explain all of wealth holding by high-school dropouts without invoking a large degree of impatience or institutional factors. It overpredicts stockholding, primarily because its incidence is extremely low among this group, and standard expected-utility models need to be otherwise augmented to account for this fact, as we have shown elsewhere. The sensitivity of conclusions to parameter values and model variants is explored extensively.

Based on these first results from setups which do not impose any frictions, market imperfections or special factors, the life-cycle model with career risk appears as a useful benchmark for future research. The model and the calibration methods introduced here should prove quite versatile and computationally tractable in allowing for finer distinctions among risky assets, investigating correlations between incomes and asset returns, considering more education and/or income categories, exploring additional dimensions of household heterogeneity, matching population frequencies, introducing important frictions, and exploring the separate contributions of various factors. 


\section{References}

Aiyagari, R. (1994). "Uninsured Idiosyncratic Risk and Aggregate Saving." Quarteriy Journal of Economics, pp. 659-84.

Aiyagari, R. and Gertler, M. (1991). "Asset Returns with Transactions Costs and Uninsured Individual Risk." Journal of Monetary Economics, vol. 27, pp. 311-31.

Auerbach, A. and Kotlikoff, L. (1987). Dynamic Fiscal Policy. Cambridge: Cambridge University Press.

Auerbach, A., Kotlikoff, L. and Skinner, J. (1983). "The Efficiency Gains from Dynamic Tax Reform." International Economic Review, vol. 24, pp. 81-100.

Bar-Ilan, A. (1991). "On the Proportionality and Homogeneity of Consumption and Income." Mimeograph, University of British Columbia.

Bernheim, D. and Scholz, K. (1993). "Private Saving and Public Policy." In J. Poterba (Ed.), Tax Policy and the Economy, vol. 7. Cambridge: MIT Press.

Carroll, C. (1992). "The Buffer Stock Theory of Saving: Some Macroeconomic Evidence." Brookings Papers on Economic Activity, vol. 1992:2, pp. 61-135.

Carroll, C. and Samwick, A. (1992). "The Nature and Magnitude of Precautionary Wealth." Working Paper No. 124, Economic Activity Section, Board of Governors of the Federal Reserve System.

Constantinides, G. and Duffie, D. (1992). "Asset Pricing with Heterogeneous Consumers." Mimeograph, University of Chicago.

Dardanoni, V. (1991). "Precautionary Savings Under Income Uncertainty: A Cross-sectional Analysis." Applied Economics, vol. 23, pp. 153-60.

Deaton, A. (1991). "Saving and Liquidity Constraints." Econometrica, vol. 59, pp. 1221-48.

Elmendorf, D. and Kimball, M. (1991). "Taxation of Labor Income and the Demand for Risky Assets." NBER Working Paper No. 3204.

Guiso, L., Jappelli, T. and Terlizzesse, D. (1992). "Earnings Uncertainty and Precautionary Saving." Journal of Monetary Economics, vol. 30, pp. 307-21.

Guiso, L., Jappelli, T. and Terlizzesse, D. (1994). "Income Risk, Borrowing Constraints, and Portfolio Choice." Mimeograph.

Haliassos, M. (1994). "On Perfect Foresight Models of a Stochastic World." The Economic Journal, vol. 104 , pp. $477-91$. 
Haliassos, M. and Bertaut, C. (1995). "Why Do So Few Hold Stocks?" The Economic Journal, vol. 105, pp. 1110-1129.

Haliassos, M. and Lyon, A. (1994). "Progressivity of Capital Gains Taxation with Optimal Portfolio Selection." In Slemrod, J. (Ed.), Tax Progressivity and Income Inequality. Cambridge: Cambridge University Press.

Heaton, J. and Lucas, D. (1992). "Evaluating the Effects of Incomplete Markets on Risk Sharing and Asset Pricing." Mimeograph.

Hubbard, G. and Judd, K. (1987). "Social Security and Individual Welfare: Precautionary Saving, Liquidity Constraints, and the Payroll Tax." American Economic Review, vol. 77, pp. 630-46.

Hubbard, R. G., Skinner, J. and Zeldes, S. (1995). "Precautionary Saving and Social Insurance." Journal of Political Economy, vol. 103, pp. 360-399.

Hubbard, G., Skinner, J. and Zeldes, S. (1994). "The Importance of Precautionary Motives in Explaining Individual and Aggregate Saving." Carnegie-Rochester Conference Series on Public Policy, vol. 40, pp. 59-125.

Kimball, M. (1990). "Precautionary Saving in the Small and in the Large." Econometrica, vol. 58, pp. 5373.

Kimball, M. (1991). "Precautionary Motives for Holding Assets." in Newman, P., Milgate, M. and Eatwell, J. (Eds.), The New Palgrave Dictionary of Money and Finance, vol. 3, pp. 158-161. New York: Stockton Press.

Kimball, M. (1993). "Standard Risk Aversion", Econometrica, vol. 61, pp. 589-612.

Kotlikoff, L. and Summers, L. (1981). "The Role of Intergenerational Transfers in Aggregate Capital Accumulation." Journal of Political Economy, vol. 89, pp. 706-32.

Leland, H. (1968). "Saving and Uncertainty: The Precautionary Demand for Saving." Quarterly Journal of Economics, vol. 82, pp. 456-73.

Mankiw, N.G., and Zeldes S. (1991). "The Consumption of Stockholders and Non-stockholders." Journal of Financial Economics, vol. 29, pp. 97-112.

Mehra, R. and Prescott, E. (1985). "The Equity Premium: A Puzzle." Journal of Monetary Economics, vol. 15, pp. 145-61.

Pratt, J. and Zeckhauser, R. (1987). "Proper Risk Aversion." Econometrica, vol 55, pp. 143-54.

Sandmo, A. (1970). "The Effect of Uncertainty on Saving Decisions." Review of Economic Studies, vol. 37, pp. 353-360. 
Schwert, G.W. (1990). "Indexes of U.S. Stock Prices from 1802-1987." Journal of Business, vol. 63, pp. $399-426$.

Siegel, J. (1992). "The Real Rate of Interest from 1800-1990: A Study of the U.S. and the U.K." Journal of Monetary Economics, vol. 29, pp. 227-52.

Skinner, J. (1988). "Risky Income, Life-cycle Consumption, and Precautionary Savings." Journal of Monetâry Economics, vol. 22, pp. 237-55.

Venti, S. and Wise. D. (1987). "IRAs and Saving." In Feldstein, M. (Ed.), The Effects of Taxation on Capital Accumulation. Chicago: Chicago University Press.

Weil, P. (1990). "Equilibrium Asset Prices with Undiversifiable Labor Income Risk." Mimeograph.

White, B. (1978). "Empirical Tests of the Life-cycle Hypothesis." American Economic Review, vol. 68, pp. 546-60.

Zeldes, S. (1989). "Optimal Consumption with Stochastic Income: Deviations from Certainty Equivalence." Quarterly Journal of Economics, pp. 275-98. 


\section{Data Appendix}

Numbers refer to variables in the 1992 Survey of Consumer Finances

1. Stocks (standard definition): dollar value of shares of publicly traded stocks (X3915) plus shares in stock mutual funds (X3822) plus $1 / 2$ of shares in combination funds (X3830) plus stocks in IRAs and Keogh plans $(=\mathrm{X} 3610+\mathrm{X} 3620+\mathrm{X} 3630$ if X3631 $=2)$ plus $1 / 2$ IRAs split between stocks and bonds or stocks and money market accounts $(=1 / 2 *(X 3610+X 3620+X 3630)$ if $X 3631=5$ or X3631=6) $+1 / 3$ of mixed stock/bond/money market accounts $(=1 / 3 *(X 3610+X 3620+X 3630)$ if $X 3631=4)$.

2. Stocks (broad definition) $=$ Stocks (standard definition) plus dollar value of stocks in trusts or managed accounts $(=$ X3942 if X3947=1) plus $1 / 2$ (trusts and managed accounts split between stocks and bonds or money market $(=1 / 2 * X 3942$ if X3947=5) $+1 / 3$ other diversified accounts $(=1 / 3 * X 3942$ if $\mathrm{X} 3947=6$ or X3947=-7) plus stocks in defined contribution pension plans plus $1 / 2$ of defined contribution plans split between stocks and interest-earning assets $(=X 4226$ if X4234 $=1$ or $1 / 2 * X 4226$ if X4234 $=3$ ) $+(X 4326$ if $X 4334=1$ or $1 / 2 * X 4326$ if $X 4334=3)+(X 4426$ if $X 4434=1$ or $1 / 2 * X 4426$ if $X 4434=3)$.

3. Financial net worth (standard definition): dollar value of transactions, savings, and money market accounts $(=X 3506+X 3510+X 3514+X 3518+X 3522+X 3526+X 3529+X 3706+X 3711+X 3716$ $+\mathrm{X} 3718+\mathrm{X} 3804+\mathrm{X} 3807+\mathrm{X} 3810+\mathrm{X} 3813+\mathrm{X} 3816+\mathrm{X} 3818+\mathrm{X} 3930)$ plus certificates of deposit (X3721) plus IRA/Keogh accounts (X3610 + X3620 + X3630) plus directly held mutual funds (X3822 $+X 3824+X 3826+X 3828+X 3830)$ plus saving bonds $(X 3902)$ plus other directly held bonds (X3910 $+\mathrm{X} 3906+\mathrm{X} 3908+\mathrm{X} 7634+\mathrm{X} 7633)$ plus cash value of whole life insurance (X4006) plus other financial assets $(X 4018+X 4022$ if $61 \leq X 4020 \leq 66$ or $72 \leq X 4020 \leq 74+X 4026$ if $61 \leq X 4024 \leq 66$ or $72 \leq$ $\mathrm{X} 4024 \leq 74+\mathrm{X} 4030$ if $61 \leq \mathrm{X} 4028 \leq 66$ or $72 \leq \mathrm{X} 4028 \leq 74)$ minus credit card balances $(X 427+\mathrm{X} 413$ $+X 421+X 430+X 424+X 7575)$ minus installment and other non-real estate loans $(X 2218+X 2318+$ $\mathrm{X} 2418+\mathrm{X} 2424+\mathrm{X} 2519+\mathrm{X} 2619+\mathrm{X} 2625+(\mathrm{X} 2723$ if $\mathrm{X} 2710$ not $=67)+(\mathrm{X} 2740$ if $\mathrm{X} 2727$ not $=67)+$ $(X 2823$ if X2810 not $=67)+(X 2840$ if X2827 not $=67)+(X 2923$ if $X 2910$ not $=67)+(X 2940$ if $X 2927$ not $=67)+X 7824+X 7847+X 7870+X 7924+X 7947+X 7970+X 1044+X 1215+X 1219+X 1108$ $+X 1119+X 1130+X 4229+X 4329+X 4429+X 4829+X 4929+X 5029+X 4010+X 4032+X 3932)$.

4. Financial net worth (broad definition): financial net worth (standard definition) plus dollar value of assets in managed or trust accounts (X3942) + amounts in defined-contribution pension plans that can be borrowed against or from which household can make a withdrawal (X4226 if $(X 4216=1$ or 2) and $(X 4227=1$ or $X 4231=1))+(X 4326$ if $(X 4316=1$ or 2$)$ and $(X 4327=1$ or $X 4331=1))+(X 4426$ if $(X 4416=1$ or 2$)$ and $(X 4427=1$ or $X 4431=1))+(X 4826$ if $(X 4816=1$ or 2$)$ and $(X+827=1$ or $X 4831=1))+(X 4926$ if $(X 4916=1$ or 2$)$ and $(X 4927=1$ or $X 9831=1))+(X 5026$ if $(X j 016=1$ or 2$)$ and $(X 5027=1$ or $\mathrm{X} 5031=1)$ ).

5. Riskless assets (standard definition) $=$ financial net worth (standard definition) - stocks (standard definition).

6. Riskless assets (broad definition $)=$ financial net worth (broad definition) - stocks (broad definition) 
7. Household labor income for 1991: household income derived from wages and salaries (X5702) plus income from professional business or practice (X5704) plus unemployment or worker's compensation (X5716) plus income from Social Security or pensions (X5722).

8. After-tax labor income: For non-retirement sources of income, the average tax rate was imputed from information on household adjusted gross income (AGI) $(=X 5751$, or X7651 and X7652) and tax filing status (X5746). The average tax rates for AGI class and filing status were calculated from the Statistics of Income-1991, Individual Income Tax Returns, Table 1.2. AGI classes were: under $\$ 1,000 ; \$ 1,000$ to under $\$ 5,000 ; \$ 5,000$ to under $\$ 10,000 ; \$ 10,000$ to under $\$ 15,000 ; \$ 15,000$ to under $\$ 20,000 ; \$ 20,000$ to under $\$ 25,000 ; \$ 25,000$ to under $\$ 30,000 ; \$ 30,000$ to under $\$ 40,000$; $\$ 40,000$ to under $\$ 50,000$; $\$ 50,000$ to under $\$ 75,000 ; \$ 75,000$ to under $\$ 100,000 ; \$ 100,000$ to under $\$ 200,000 ; \$ 200,000$ to under $\$ 500,000 ; \$ 500,000$ to under $\$ 1,000,000$; and $\$ 1,000,000$ or more. Filing status was single, married filing a joint return, or married filing separate returns. For married couples filing separate returns, a weighted average tax rate (reflecting each spouse's AGI) was constructed. Total after-tax income $=$ income from retirement sources $($ X5722 $)+(1-\text { tax rate })^{*}(X 5702+X 5704+$ X5716).

9. Age of household head: recoded from X8022 as 5-year spreads between 20 and over 85 for income calibrations, and as 10-year spreads between 20 and over 80 for portfolio estimates.

10. Education of household head: recoded from X5901, X5902, and X5904 as (i) no high school degree (ii) high school degree or equivalency certificate but no college degree and (iii) college degree or higher.

The final data set included 3,906 respondents. All variables were weighted with XWGT to produce population averages. 


\section{Appendix II}

\begin{tabular}{|c|c|c|c|c|c|}
\hline \multicolumn{6}{|c|}{$\begin{array}{c}\text { Table A1. Calibrated Income Processes for Population Models, } \\
\text { by Education Group }\end{array}$} \\
\hline & \multicolumn{5}{|c|}{ Equivalent Incomes in Period and State } \\
\hline \multicolumn{6}{|c|}{$\begin{array}{l}\text { Education: } \\
\text { Less than High School }\end{array}$} \\
\hline Income Category & frequency & $Y 1$ & Y2 High & Y2 Low & Y3 \\
\hline 1 & 0.2297 & 8778.3 & 21903.6 & 7780.4 & 13633 \\
\hline 2 & 0.5224 & 13947.1 & 30467.8 & 11026.2 & 13633 \\
\hline 3 & 0.1917 & 20907.4 & 40316 & 15200 & 13633 \\
\hline 4 & 0.0426 & 28279.0 & 50289 & 19551 & 13633 \\
\hline 5 & 0.0102 & 35624.3 & 60404 & 23780 & 13633 \\
\hline 6 & 0.0023 & 42741.5 & 68235 & 27777 & 13633 \\
\hline 7 & 0.0008 & 50821.6 & 67703 & 28423 & 13633 \\
\hline 8 & 0.0002 & 58421.8 & 55836 & 25324 & 13633 \\
\hline 9 & 0 & -- & -- & -- & -- \\
\hline 10 & 0.0001 & 77412.6 & 125043 & 61187 & 13633 \\
\hline \multicolumn{6}{|l|}{$\begin{array}{l}\text { High School } \\
\text { Income Category }\end{array}$} \\
\hline 1 & 0.0629 & 13202.1 & 33605.2 & 15174.8 & 22032 \\
\hline 2 & 0.3941 & 19806.9 & 43289 & 20081 & 22032 \\
\hline 3 & 0.3429 & 27444.9 & 53199 & 25383 & 22032 \\
\hline 4 & 0.1429 & 35971.5 & 63547 & 30573 & 22032 \\
\hline 5 & 0.0398 & 44459.3 & 73243 & 35293 & 22032 \\
\hline 6 & 0.0127 & 52907.1 & 81405 & 40183 & 22032 \\
\hline 7 & 0.0032 & 61325.9 & 94176 & 46884 & 22032 \\
\hline 8 & 0.0009 & 68909.3 & 100510 & 51582 & 22032 \\
\hline 9 & 0.0005 & 79660.9 & 123572 & 66474 & 22032 \\
\hline 10 & 0.0001 & 92801.6 & 165371 & 95669 & 22032 \\
\hline \multicolumn{6}{|l|}{$\begin{array}{l}\text { College or More } \\
\text { Income Category }\end{array}$} \\
\hline 1 & 0.1154 & 23738.1 & 70964 & 36698 & 49663 \\
\hline 2 & 0.4486 & $33606 . \overline{2}$ & 88944 & 45850 & 49663 \\
\hline 3 & 0.3114 & 45252.4 & 109620 & 57380 & 49663 \\
\hline 4 & 0.0956 & 57920.9 & 129691 & 69023 & 49663 \\
\hline 5 & 0.0219 & 70548.4 & 146945 & 79755 & 49663 \\
\hline 6 & 0.0058 & 83099.4 & 164253 & 89567 & 49663 \\
\hline 7 & 0.001 & 96697.8 & 178094 & 102826 & 49663 \\
\hline 8 & 0.0002 & 105650.0 & 158597 & 91883 & 49663 \\
\hline 9 & 0 & -- & - & $-\cdot$ & -- \\
\hline 10 & 0.0001 & 142906.0 & 246917 & 149563 & 49663 \\
\hline \multicolumn{6}{|c|}{$\begin{array}{l}\text { First-period incomes for each education level are derived from } 10.000 \text { random draws which } \\
\text { are used to construct } 10 \text { income categories. Second-period incomes for each category are } \\
\text { generated from additional random draws and allow for persistent effects of first-period shocks } \\
\text { into the second period. } \\
\text { Frequency: fraction of } 10.000 \text { households in simulated population which belong to that } \\
\text { category based on first-period income. }\end{array}$} \\
\hline
\end{tabular}


Table 1. Average and Median Dollar Holdings of Directly Held Stocks and Household Financial Net Worth for U.S. Households, by Age and Level of Education of Household Head

\begin{tabular}{|c|c|c|c|c|c|c|}
\hline \multirow[b]{2}{*}{ Age } & \multicolumn{3}{|c|}{ Average Portfolio } & \multicolumn{3}{|c|}{ Median Portfolio } \\
\hline & $\begin{array}{l}\text { Stocks } \\
\text { (1) }\end{array}$ & $\begin{array}{l}\text { Financial } \\
\text { Net Worth } \\
\text { (2) }\end{array}$ & $\begin{array}{c}\text { Stock } \\
\text { Share } \\
\text { (3) }\end{array}$ & $\begin{array}{l}\text { Stocks } \\
\text { (4) }\end{array}$ & $\begin{array}{c}\text { Financial } \\
\text { Net Worth } \\
\text { (5) }\end{array}$ & $\begin{array}{c}\text { Stock } \\
\text { Share } \\
(6)\end{array}$ \\
\hline \multicolumn{7}{|c|}{ Education: less than high school degree } \\
\hline $20-29$ years & 0 & 1977 & 0.00 & 0 & 3240 & 0.00 \\
\hline $30-39$ years & 100 & 1191 & 0.08 & 0 & 3400 & 0.00 \\
\hline $40-49$ years & 6701 & 16335 & 0.41 & 0 & 3510 & 0.00 \\
\hline $50-59$ years & 3073 & 15040 & 0.20 & 0 & 3510 & 0.00 \\
\hline $60-69$ years & 2310 & 23025 & 0.10 & 0 & 3710 & 0.00 \\
\hline $70-79$ years & 1227 & 40885 & 0.03 & 0 & 6410 & 0.00 \\
\hline $80+$ years & 28971 & 63886 & 0.45 & 0 & 4610 & 0.00 \\
\hline \multicolumn{7}{|c|}{ Education: high school degree } \\
\hline $20-29$ years & 443 & 5152 & 0.09 & 0 & 3270 & 0.00 \\
\hline $30-39$ years & 1531 & 12322 & 0.12 & 0 & 3510 & 0.00 \\
\hline $40-49$ years & 19421 & 34698 & 0.56 & 0 & 4610 & 0.00 \\
\hline 50.59 years & 27416 & 64977 & 0.42 & 0 & 15010 & 0.00 \\
\hline $60-69$ years & 30513 & 92990 & 0.33 & 0 & 25710 & 0.00 \\
\hline $70-79$ years & 37663 & 123407 & 0.31 & 0 & 32590 & 0.00 \\
\hline $80+$ years & 41244 & 87524 & 0.47 & 0 & 9060 & 0.00 \\
\hline \multicolumn{7}{|c|}{ Education: college degree } \\
\hline $20-29$ years & 10610 & 18812 & 0.56 & 0 & 3111 & 0.00 \\
\hline $30-39$ years & 19515 & 34972 & 0.56 & 0 & 8410 & 0.00 \\
\hline $40-49$ years & 35604 & 97077 & 0.37 & 300 & 20310 & 0.01 \\
\hline $50-59$ years & 73453 & 202835 & 0.36 & 2500 & 66461 & 0.04 \\
\hline $60-69$ years & 105302 & 259167 & 0.41 & 8500 & 77600 & 0.11 \\
\hline $70-79$ years & 73308 & 226199 & 0.32 & 1000 & 87410 & 0.01 \\
\hline $80+$ years & 269942 & 526430 & 0.51 & 1000 & 127710 & 0.01 \\
\hline \multicolumn{7}{|c|}{$\begin{array}{l}\text { Data: } 1992 \text { Survey of Consumer Finances } \\
\text { Directly held stocks include shares of publicly traded stocks, shares in mutual stock funds, and stocks in } \\
\text { IRAs and Keoghs. } \\
\text { Directly held household financial net worth includes directly held stocks, checking, saving, money } \\
\text { market, and call accounts, CDs, saving and other bonds, and the cash value of life insurance, minus } \\
\text { balances on credit cards, consumer loans, and other non-real estate loans. }\end{array}$} \\
\hline
\end{tabular}


Table 2. Average and Median Dollar Holdings of Directly and Indirectly Held Stocks and Household Financial Net Worth for U.S. Households, by Age and Level of Education of Household Head

Age

\begin{tabular}{|c|c|c|c|c|c|}
\hline \multicolumn{3}{|c|}{ Average Portfolio } & \multicolumn{3}{|c|}{ Median Portfolio } \\
\hline $\begin{array}{c}\text { Stocks } \\
\text { (1) }\end{array}$ & $\begin{array}{c}\text { Financial } \\
\text { Net Worth } \\
\text { (2) }\end{array}$ & $\begin{array}{c}\text { Stock } \\
\text { Share } \\
\text { (3) }\end{array}$ & $\begin{array}{c}\text { Stocks } \\
\text { (4) }\end{array}$ & $\begin{array}{c}\text { Financial } \\
\text { Net Worth } \\
\text { (5) }\end{array}$ & $\begin{array}{c}\text { Stock } \\
\text { Share } \\
\text { (6) }\end{array}$ \\
\hline
\end{tabular}

Education: less than high school degree

$20-29$

216

3106

0.07

3510

0.00

$30-39$

314

1411

0.22

3510

0.00

$40-49$

6854

16792

0.41

3510

0.00

$50-59$

3431

15063

0.23

3510

0.00

$60-69$

2394

23039

0.10

3710

0.00

$70-79$

3019

46620

0.06

6410

0.00

$80+$

29305

66055

0.44

4610

0.00

Education: high school degree

$20-29$

1043

$30-39$

4321

6468

0.16

3370

0.00

$40-49$

24278

15760

0.27

0

3610

0.00

$50-59$

$60-69$

41131

41204

0.59

5540

0.00

$70-79$

33149

76739

0.54

18510

0.00

98974

0.33

38614

127756

0.30

29010

0.00

$80+$

43738

93979

0.47

34060

0.00

Education: college degree

$20-29$

11567

22322

0.52

42792

0.58

0

9060

0.00

$30-39$

25030

116736

0.41

6000

3170

0.00

$40-49$

47792

258840

0.48

24000

28310

0.03

$50-59$

118998

285405

0.42

25000

86910

0.30

$60-69$

83792

245403

0.34

89910

0.36

$70-79$

316030

705758

0.45

1250

93010

0.32

$80+$

Consumer Finances.

Directly and indirectly held stocks include all stocks listed in Table 1, plus stocks held in defined contribution pension plans, trusts, and managed investment accounts.

Directly and indirectly held household financial net worth includes all assets listed in Table 1, plus assets held in defined contribution pension plans, trusts, and managed investment accounts. 
Table 3. Calibrated Income Processes for Representative Agent Models, by Education Group

\begin{tabular}{|c|c|c|c|c|}
\hline & \multicolumn{4}{|c|}{ Equivalent Income in Period and State } \\
\hline \multicolumn{5}{|l|}{ Income Certainty } \\
\hline Education: & Y1 & \multicolumn{2}{|c|}{$\mathrm{Y} 2$} & Y3 \\
\hline Less than High School & 15019 & \multicolumn{2}{|c|}{21570} & 13633 \\
\hline High School & 25920 & \multicolumn{2}{|c|}{37583} & 22032 \\
\hline College or More & 39483 & \multicolumn{2}{|c|}{75527} & 49663 \\
\hline \multicolumn{5}{|l|}{ Income Risk } \\
\hline & Y1 & \multicolumn{2}{|c|}{ Y2 } & Y3 \\
\hline \multicolumn{2}{|l|}{ Education: } & High & Low & \\
\hline Less than High School & 15019 & 30088.5 & 13219.5 & 13633 \\
\hline High School & 25920 & 48691 & 26219 & 22032 \\
\hline College or More & 39483 & 96010 & 55338 & 49663 \\
\hline \multicolumn{5}{|c|}{$\begin{array}{l}\text { Income values are "equivalent" incomes which, if received each year } \\
\text { over a twenty-year period, would yield present values of income equal } \\
\text { to those derived in the actual calibrations. } \\
\text { Income Certainty: Income values for periods } 1,2 \text {, and } 3 \text { are based on } \\
\text { mean incomes in the } 1992 S C F \text { for the age-education group specified. } \\
\text { Income Risk: High and low income states in period } 2 \text { are derived on } \\
\text { the basis of random draws of income shocks, and random draws of the } \\
\text { corresponding income sequences, as described in the text. Incomes are } \\
\text { adjusted to restore means to their certainty levels. Income definitions } \\
\text { are given in the data appendix. }\end{array}$} \\
\hline
\end{tabular}




\begin{tabular}{|c|c|c|c|c|c|c|c|}
\hline \multirow[t]{2}{*}{ Step } & \multirow[t]{2}{*}{ Changes to income process } & \multicolumn{3}{|c|}{ First-Period Portfolio Solutions } & \multicolumn{3}{|c|}{$\begin{array}{c}\text { Changes in Portfolio } \\
\text { Solutions from Previous Step }\end{array}$} \\
\hline & & $\begin{array}{l}W / Y \\
(1)\end{array}$ & $\begin{array}{l}S / Y \\
(2)\end{array}$ & $\begin{array}{l}\mathrm{B} / \mathrm{Y} \\
(3)\end{array}$ & $\begin{array}{c}\Delta W / Y \\
(4)\end{array}$ & $\underset{(5)}{\Delta S / Y}$ & $\begin{array}{c}\Delta \mathrm{B} / \mathrm{Y} \\
(6)\end{array}$ \\
\hline 1 & income process for LTHS & -0.320 & 0.363 & -0.683 & -- & - & -- \\
\hline 2 & $\begin{array}{l}\text { from step } 1 \text {. change non-shock } \\
\text { income level to HS }\end{array}$ & -0.311 & 0.362 & -0.672 & 0.009 & -0.001 & 0.011 \\
\hline 3 & $\begin{array}{l}\text { from step } 2 \text {, change variance of } \\
\text { persistent shocks } e \text { to HS }\end{array}$ & -0.335 & 0.374 & -0.709 & -0.024 & 0.012 & -0.036 \\
\hline 4 & $\begin{array}{l}\text { from step } 3 \text {, change serial } \\
\text { correlation of shocks to HS }\end{array}$ & -0.343 & 0.378 & -0.721 & -0.009 & 0.004 & -0.013 \\
\hline 5 & $\begin{array}{l}\text { from step } 4 \text {, change transitory } \\
\text { shocks } v \text { to HS } \\
=\text { income process for HS }\end{array}$ & -0.343 & 0.378 & -0.721 & 0.000 & 0.000 & 0.000 \\
\hline 6 & $\begin{array}{l}\text { from step } 5 \text {, change no-shock } \\
\text { income level to COL }\end{array}$ & -0.663 & 0.464 & -1.126 & -0.319 & 0.086 & -0.405 \\
\hline 7 & $\begin{array}{l}\text { from step } 6 . \text { change tax rate on } \\
\text { dividends and interest income }\end{array}$ & -0.739 & 0.465 & -1.204 & -0.076 & 0.001 & -0.077 \\
\hline 8 & $\begin{array}{l}\text { from step } 7 \text {, change variance } \\
\text { of persistent shocks } e \text { to } \mathrm{COL}\end{array}$ & -0.784 & 0.484 & -1.268 & -0.044 & 0.020 & -0.064 \\
\hline 9 & $\begin{array}{l}\text { from step } 8 \text {, change serial } \\
\text { correlation shocks to COL }\end{array}$ & -0.774 & 0.480 & -1.254 & 0.009 & -0.004 & 0.014 \\
\hline 10 & $\begin{array}{l}\text { from step } 9 \text {, change transitory } \\
\text { shocks } v \text { to COL } \\
=\text { income process for COL }\end{array}$ & -0.775 & 0.480 & -1.255 & -0.001 & 0.000 & -0.001 \\
\hline \multicolumn{8}{|c|}{$\begin{array}{l}\text { Notes: LTHS: less than high school education; HS: high school degree; } \mathrm{COL} \text { : College degree. } \\
\text { W/Y: average wealth/average income; } \mathrm{S} / \mathrm{Y} \text { : average stocks/average income; } \mathrm{B} / \mathrm{Y} \text { : average bonds/average } \\
\text { income. } \\
\text { The table shows the effects on portfolio allocation of gradually converting the income process for the } \\
\text { representative agent household with less than high school education into the process for the college- } \\
\text { educated household. Mean incomes are computed from the } 1992 \mathrm{SCF} \text {. Income definitions are given in the } \\
\text { data appendix. The calibration method is analogous to that used in Table } 3 \text {. }\end{array}$} \\
\hline
\end{tabular}




\begin{tabular}{|c|c|c|c|c|c|c|c|}
\hline \multirow{2}{*}{$\begin{array}{l}\text { Degree of } \\
\text { Risk } \\
\text { Aversion }\end{array}$} & \multirow{2}{*}{$\begin{array}{c}\text { Certain } \\
\text { Income, } \\
\text { No Bequests } \\
\text { W/Y } \\
\text { Rep Agent } \\
\text { (1) }\end{array}$} & \multicolumn{2}{|c|}{$\begin{array}{c}\text { Income Risk, } \\
\text { No Bequests } \\
\text { W/Y }\end{array}$} & \multicolumn{2}{|c|}{$\begin{array}{c}\text { Income Risk, } \\
\text { Bequests } \\
\text { W/Y }\end{array}$} & \multicolumn{2}{|c|}{$\begin{array}{l}\text { Income Risk, } \\
\text { Population M̀odeis } \\
\text { Med W/Med Y }\end{array}$} \\
\hline & & $\begin{array}{c}\text { Rep Agent } \\
\text { (2) }\end{array}$ & $\begin{array}{l}\text { Population } \\
\text { (3) }\end{array}$ & $\begin{array}{c}\text { Rep Agent } \\
\text { (4) }\end{array}$ & $\begin{array}{l}\text { Population } \\
\text { (5) }\end{array}$ & $\begin{array}{c}\text { No } \\
\text { Bequests } \\
(6)\end{array}$ & $\begin{array}{c}\text { Bequests } \\
\text { (7) }\end{array}$ \\
\hline \multicolumn{8}{|c|}{ Education: less than high school degree } \\
\hline 2 & -0.58 & -0.45 & -0.41 & -0.36 & -0.32 & -0.45 & -0.36 \\
\hline 3 & -0.45 & -0.32 & -0.28 & -0.19 & -0.15 & -0.32 & -0.19 \\
\hline 4 & -0.37 & -0.24 & -0.20 & $-0.0 \overline{8}$ & -0.05 & -0.23 & -0.08 \\
\hline 5 & -0.33 & -0.18 & -0.14 & -0.01 & 0.02 & -0.18 & -0.01 \\
\hline 6 & -0.29 & -0.15 & -0.10 & 0.03 & 0.07 & -0.14 & 0.04 \\
\hline 7 & -0.27 & -0.12 & -0.07 & 0.07 & 0.10 & -0.11 & 0.08 \\
\hline 8 & -0.25 & -0.09 & -0.05 & 0.10 & 0.13 & -0.09 & 0.10 \\
\hline 9 & -0.24 & -0.08 & -0.04 & 0.12 & 0.15 & -0.07 & 0.12 \\
\hline 10 & -0.22 & -0.06 & -0.02 & 0.13 & 0.17 & -0.05 & 0.14 \\
\hline \multicolumn{8}{|c|}{ Education: high school degree } \\
\hline 2 & -0.55 & -0.47 & -0.44 & -0.38 & -0.35 & -0.42 & -0.33 \\
\hline 3 & -0.43 & -0.34 & -0.31 & -0.21 & -0.18 & -0.29 & -0.16 \\
\hline 4 & -0.35 & -0.26 & -0.23 & -0.10 & -0.08 & -0.21 & -0.06 \\
\hline 5 & -0.31 & -0.21 & -0.18 & -0.04 & -0.01 & -0.16 & 0.01 \\
\hline 6 & -0.27 & -0.17 & -0.14 & 0.01 & 0.04 & -0.12 & 0.05 \\
\hline 7 & -0.25 & -0.14 & -0.11 & 0.05 & 0.07 & -0.09 & 0.09 \\
\hline 8 & -0.23 & -0.12 & -0.09 & 0.07 & 0.10 & -0.07 & 0.11 \\
\hline 9 & -0.22 & -0.11 & -0.07 & 0.09 & 0.12 & -0.06 & 0.13 \\
\hline 10 & -0.21 & -0.09 & -0.06 & 0.11 & 0.14 & -0.04 & 0.15 \\
\hline \multicolumn{8}{|c|}{ Education: college degree } \\
\hline 2 & -1.06 & -0.97 & -0.93 & -0.84 & -0.80 & -1.09 & -0.95 \\
\hline 3 & -0.87 & -0.77 & -0.74 & -0.58 & -0.55 & -0.88 & -0.67 \\
\hline 4 & -0.76 & -0.66 & -0.62 & -0.43 & -0.40 & -0.75 & -0.51 \\
\hline 5 & -0.69 & -0.58 & -0.54 & -0.33 & -0.30 & -0.67 & -0.41 \\
\hline 6 & -0.64 & -0.53 & -0.49 & -0.27 & -0.24 & -0.61 & -0.34 \\
\hline 7 & -0.60 & -0.49 & -0.45 & -0.22 & -0.19 & -0.57 & -0.28 \\
\hline 8 & -0.58 & -0.46 & -0.42 & -0.18 & -0.15 & -0.53 & -0.24 \\
\hline 9 & -0.56 & $-0.4 \overline{3}$ & $-\overline{0} . \overline{3} \overline{9}$ & -0.15 & -0.12 & -0.50 & $-0.2 \mathrm{i}$ \\
\hline 10 & -0.54 & -0.41 & -0.37 & -0.13 & -0.10 & -0.48 & -0.19 \\
\hline \multicolumn{8}{|c|}{$\begin{array}{l}\text { Notes: W/Y: Ratio of average wealth to average income. } \\
\text { Med W/Med Y: Ratio of median wealth to median income. } \\
\text { Certain Income: Baseline model with no second-period income shocks. } \\
\text { Income Risk: Adds transitory and persistent shocks to second-period incomes. } \\
\text { Rep Agent: Representative agent models. } \\
\text { Population: Models with populations of heterogenous agents. } \\
\text { Bequests: Models with bequest motives; the weight on the bequest motive } \lambda=0.25 \text { (see equation (7)). } \\
\text { Aili modeis have rate of time preference } \delta=3.13 \text { percent per annum. }\end{array}$} \\
\hline
\end{tabular}


Table 6: Comparison of Model Predictions of First-Period Stocks to Income Ratios, by Education and Degree of Risk Aversion

\begin{tabular}{|c|c|c|c|c|c|c|c|}
\hline \multirow{2}{*}{$\begin{array}{l}\text { Degree of } \\
\text { Risk } \\
\text { Aversion }\end{array}$} & \multirow{2}{*}{$\begin{array}{c}\text { Certain } \\
\text { Income, } \\
\text { No Bequests } \\
\text { S/Y } \\
\text { Rep Agent } \\
\text { (1) }\end{array}$} & \multicolumn{2}{|c|}{$\begin{array}{c}\text { Income Risk, } \\
\text { No Bequests } \\
\mathrm{S} / \mathrm{Y}\end{array}$} & \multicolumn{2}{|c|}{$\begin{array}{l}\text { Income Risk. } \\
\text { Bequests } \\
\text { S/Y }\end{array}$} & \multicolumn{2}{|c|}{$\begin{array}{l}\text { Income Risk, } \\
\text { Population Models } \\
\text { Med S/Med Y }\end{array}$} \\
\hline & & $\begin{array}{c}\text { Rep Agent } \\
\text { (2) }\end{array}$ & $\begin{array}{l}\text { Population } \\
\text { (3) }\end{array}$ & $\begin{array}{c}\text { Rep Agent } \\
\text { (4) }\end{array}$ & $\begin{array}{l}\text { Population } \\
\text { (5) }\end{array}$ & $\begin{array}{l}\text { No } \\
\text { Bequests } \\
\text { (6) }\end{array}$ & $\begin{array}{c}\text { Bequests } \\
\text { (7) }\end{array}$ \\
\hline \multicolumn{8}{|c|}{ Education: less than high school degree } \\
\hline 2 & 0.72 & 0.63 & 0.60 & 0.68 & 0.65 & 0.62 & 0.66 \\
\hline 3 & 0.43 & 0.36 & 0.34 & 0.40 & 0.38 & 0.35 & 0.39 \\
\hline 4 & 0.30 & 0.25 & 0.24 & 0.28 & 0.27 & 0.25 & 0.28 \\
\hline 5 & 0.23 & 0.10 & 0.18 & 0.22 & 0.21 & 0.19 & 0.21 \\
\hline 6 & 0.19 & 0.10 & 0.15 & 0.18 & 0.17 & 0.15 & 0.17 \\
\hline 7 & 0.16 & 0.13 & 0.12 & 0.15 & 0.14 & 0.13 & 0.15 \\
\hline 8 & 0.14 & 0.11 & 0.11 & 0.13 & 0.12 & 0.11 & 0.13 \\
\hline 9 & 0.12 & 0.10 & 0.10 & 0.11 & 0.11 & 0.10 & 0.11 \\
\hline 10 & 0.11 & 0.09 & 0.09 & 0.10 & 0.10 & 0.09 & 0.10 \\
\hline \multicolumn{8}{|c|}{ Education: high school degree } \\
\hline 2 & 0.71 & 0.65 & 0.63 & 0.70 & 0.68 & 0.62 & 0.66 \\
\hline 3 & 0.42 & 0.38 & 0.36 & 0.42 & 0.40 & 0.36 & 0.40 \\
\hline 4 & 0.30 & 0.26 & 0.25 & 0.29 & 0.28 & 0.25 & 0.28 \\
\hline 5 & 0.23 & 0.20 & 0.19 & 0.23 & 0.22 & 0.19 & 0.21 \\
\hline 6 & 0.19 & 0.16 & 0.16 & 0.18 & 0.18 & 0.15 & 0.17 \\
\hline 7 & 0.16 & 0.14 & 0.13 & 0.15 & 0.15 & 0.13 & 0.15 \\
\hline 8 & 0.14 & 0.12 & 0.11 & 0.13 & 0.13 & 0.11 & 0.13 \\
\hline 9 & 0.12 & 0.10 & 0.10 & 0.12 & 0.11 & 0.10 & 0.11 \\
\hline 10 & 0.11 & 0.09 & 0.09 & 0.10 & 0.10 & 0.09 & 0.10 \\
\hline \multicolumn{8}{|c|}{ Education: college degree } \\
\hline 2 & 0.87 & 0.80 & 0.78 & 0.86 & 0.84 & 0.84 & 0.91 \\
\hline 3 & 0.53 & 0.48 & 0.46 & 0.53 & 0.51 & 0.50 & 0.55 \\
\hline 4 & 0.38 & 0.34 & 0.33 & 0.38 & 0.36 & 0.35 & 0.39 \\
\hline 5 & 0.29 & 0.26 & 0.25 & 0.29 & 0.28 & 0.27 & 0.30 \\
\hline 6 & 0.24 & 0.21 & 0.20 & 0.24 & 0.23 & 0.22 & 0.25 \\
\hline 7 & 0.20 & 0.18 & 0.17 & 0.20 & 0.19 & 0.18 & 0.21 \\
\hline 8 & 0.18 & 0.15 & 0.15 & 0.17 & 0.17 & 0.16 & 0.18 \\
\hline 9 & 0.15 & 0.13 & 0.13 & 0.15 & 0.15 & 0.14 & 0.16 \\
\hline 10 & 0.14 & 0.12 & 0.12 & 0.13 & 0.13 & 0.12 & 0.14 \\
\hline \multicolumn{8}{|c|}{$\begin{array}{l}\text { Notes: W/Y: Ratio of average wealth to average income. } \\
\text { Med W/Med Y: Ratio of median wealth to median income. } \\
\text { Certain Income: Baseline model with no second-period income shocks. } \\
\text { Income Risk: Adds transitory and persistent shocks to second-period incomes. } \\
\text { Rep Agent: Representative agent models. } \\
\text { Population: Models with populations of heterogenous agents. } \\
\text { Bequests: Models with bequest motives; the weight on the bequest motive } \lambda=0.25 \text { (see equation (7)). } \\
\text { All models have rate of time preference } \delta=3.13 \text { percent per annum. }\end{array}$} \\
\hline
\end{tabular}


Table 7. Ratios of Average and Median Financial Net Worth and Stocks to After-tax Labor Income, for U.S. Households, by Age and Level of Education of Household Head

\begin{tabular}{|c|c|c|c|c|c|c|c|c|}
\hline \multirow[b]{2}{*}{ Age } & \multicolumn{4}{|c|}{ Directly Held Assets } & \multicolumn{4}{|c|}{ Directly and Indirectly Held Assets } \\
\hline & $\begin{array}{l}W / Y \\
\text { (1) } \\
\end{array}$ & $\begin{array}{l}S / Y \\
(2) \\
\end{array}$ & $\begin{array}{c}\text { Med W/ } \\
\text { Med Y } \\
(3) \\
\end{array}$ & $\begin{array}{l}\text { Med S/ } \\
\text { Med Y } \\
(4) \\
\end{array}$ & $\begin{array}{c}\mathrm{W}^{\mathrm{b}} / \mathrm{Y} \\
(5) \\
\end{array}$ & $\begin{array}{c}S^{b} / Y \\
(6) \\
\end{array}$ & $\begin{array}{c}\text { Med Wb/ } \\
\text { Med Y } \\
(7)\end{array}$ & $\begin{array}{c}\text { Med S } / \\
\text { Med Y } \\
(8)\end{array}$ \\
\hline \multicolumn{9}{|c|}{ Education: less than high school degree } \\
\hline $20-29$ years & 0.16 & 0.00 & 0.32 & 0.00 & 0.25 & 0.02 & 0.35 & 0.00 \\
\hline $30-39$ years & 0.07 & 0.01 & 0.27 & 0.00 & 0.08 & 0.02 & 0.28 & 0.00 \\
\hline $40-49$ years & 0.88 & 0.36 & 0.27 & 0.00 & 0.90 & 0.37 & 0.27 & 0.00 \\
\hline $50-59$ years & 0.61 & 0.12 & 0.21 & 0.00 & $0.6 \mathrm{i}$ & 0.14 & $0.2 \mathrm{i}$ & 0.00 \\
\hline $60-69$ years & 1.48 & 0.15 & 0.31 & 0.00 & 1.48 & 0.15 & 0.31 & 0.00 \\
\hline $70-79$ years & 3.54 & 0.11 & 0.75 & 0.00 & 4.04 & 0.26 & 0.75 & 0.00 \\
\hline $80+$ years & 7.30 & 3.31 & 0.70 & 0.00 & 7.55 & 3.35 & 0.70 & 0.00 \\
\hline \multicolumn{9}{|c|}{ Education: high school degree } \\
\hline $20-29$ years & 0.26 & 0.02 & 0.19 & 0.00 & 0.33 & 0.05 & 0.20 & 0.00 \\
\hline $30-39$ years & 0.36 & 0.04 & 0.13 & 0.00 & 0.46 & 0.13 & 0.13 & 0.00 \\
\hline $40-\frac{49}{79}$ years & 0.90 & 0.50 & 0.14 & 0.00 & 1.07 & 0.63 & 0.17 & 0.00 \\
\hline $50-59$ years & 1.72 & 0.73 & 0.50 & 0.00 & 2.04 & 1.09 & 0.62 & 0.00 \\
\hline $60-69$ years & 3.44 & 1.13 & 1.43 & 0.00 & 3.67 & 1.23 & 1.61 & 0.00 \\
\hline $70-79$ years & 7.34 & 2.24 & 2.72 & 0.00 & 7.60 & 2.30 & 2.84 & 0.00 \\
\hline $80+$ years & 7.84 & 3.69 & 0.98 & 0.00 & 8.41 & 3.92 & 0.98 & 0.00 \\
\hline \multicolumn{9}{|c|}{ Education: college degree } \\
\hline $20-29$ years & 0.66 & 0.37 & 0.14 & 0.00 & 0.78 & 0.41 & 0.14 & 0.00 \\
\hline $30-39$ years & 0.63 & 0.35 & 0.21 & 0.00 & 0.77 & 0.45 & 0.23 & 0.01 \\
\hline $40-49$ years & 1.51 & 0.55 & 0.44 & 0.01 & 1.81 & 0.74 & 0.62 & 0.13 \\
\hline $50-59$ years & 2.33 & 0.84 & 1.15 & 0.04 & 2.97 & 1.42 & 1.50 & 0.38 \\
\hline $60-69$ years & 4.11 & 1.67 & 1.94 & 0.21 & 4.52 & 1.89 & 2.25 & 0.56 \\
\hline $70-79$ years & 5.97 & 1.93 & 3.92 & 0.04 & 6.47 & 2.21 & 4.17 & 0.06 \\
\hline $80+$ years & 14.86 & 7.62 & 7.98 & 0.06 & 19.93 & 8.92 & 13.34 & 0.09 \\
\hline \multicolumn{9}{|c|}{$\begin{array}{l}\text { Data: } 1992 \text { Survey of Consumer Finances. } \\
\text { Directly held assets: See notes to Table } 1 . \mathrm{W} \text { : Directly held financial net worth. S: Directly held } \\
\text { stocks. } \\
\text { Directly and indirectly held assets: See notes to Table } 2 . \mathrm{W}^{\mathrm{b}} \text { : Directly and indirectly held financial ne } \\
\text { worth } \mathrm{S}^{\mathrm{b}} \text { : Directiy and indirectly held stocks. } \\
\mathrm{Y} \text { : After-tax labor income. } \\
\mathrm{W} / \mathrm{Y} \text { and } \mathrm{W}^{\mathrm{b}} / \mathrm{Y} \text { : Ratio of average financial net worth in age-education cell to average after-tax labor } \\
\text { income in age-education cell. } \\
\mathrm{S} / \mathrm{Y} \text { and } \mathrm{S}^{\mathrm{b}} / \mathrm{Y} \text { : Ratio of average stocks to average after-tax labor income. } \\
\text { Med W/Med } \mathrm{Y} \text { and Med } \mathrm{W}^{\mathrm{b}} / \mathrm{Med} \mathrm{Y} \text { : ratio of median financial net worth in age-education cell to } \\
\text { median after-tax labor income in age-education cell. } \\
\text { Med S/Med } \mathrm{Y} \text { and Med } \mathrm{S}^{\mathrm{t}} / \mathrm{Med} \mathrm{Y} \text { : Ratio of median stocks to median after-tax labor income. }\end{array}$} \\
\hline
\end{tabular}




\begin{tabular}{||c|c|c|c|c||}
\hline \multicolumn{5}{||c|}{ Table 8. Declared Willingness to Undertake Financial Risks, by Education Level } \\
\hline $\begin{array}{c}\text { Household } \\
\text { Response }\end{array}$ & $\begin{array}{c}\text { Total Population } \\
(\%)\end{array}$ & $\begin{array}{c}\text { Less Than High School } \\
(\%)\end{array}$ & $\begin{array}{c}\text { High School } \\
(\%)\end{array}$ & $\begin{array}{c}\text { College } \\
(\%)\end{array}$ \\
\hline High Risk & 14 & 5 & 12 & 23 \\
\hline $\begin{array}{c}\text { Average } \\
\text { Risk }\end{array}$ & 37 & 18 & 36 & 50 \\
\hline No Risk & 48 & 78 & 52 & 27 \\
\hline $\begin{array}{l}\text { Source: Computed from the 1992 Survey of Consumer Finances. } \\
\text { High Risk: Willing to undertake substantial risk for substantial return or above average } \\
\text { risk for above average return. Average Risk: Willing to take average risk expecting } \\
\text { average return. No Risk: Not willing to undertake any financial risk. }\end{array}$ \\
\hline
\end{tabular}




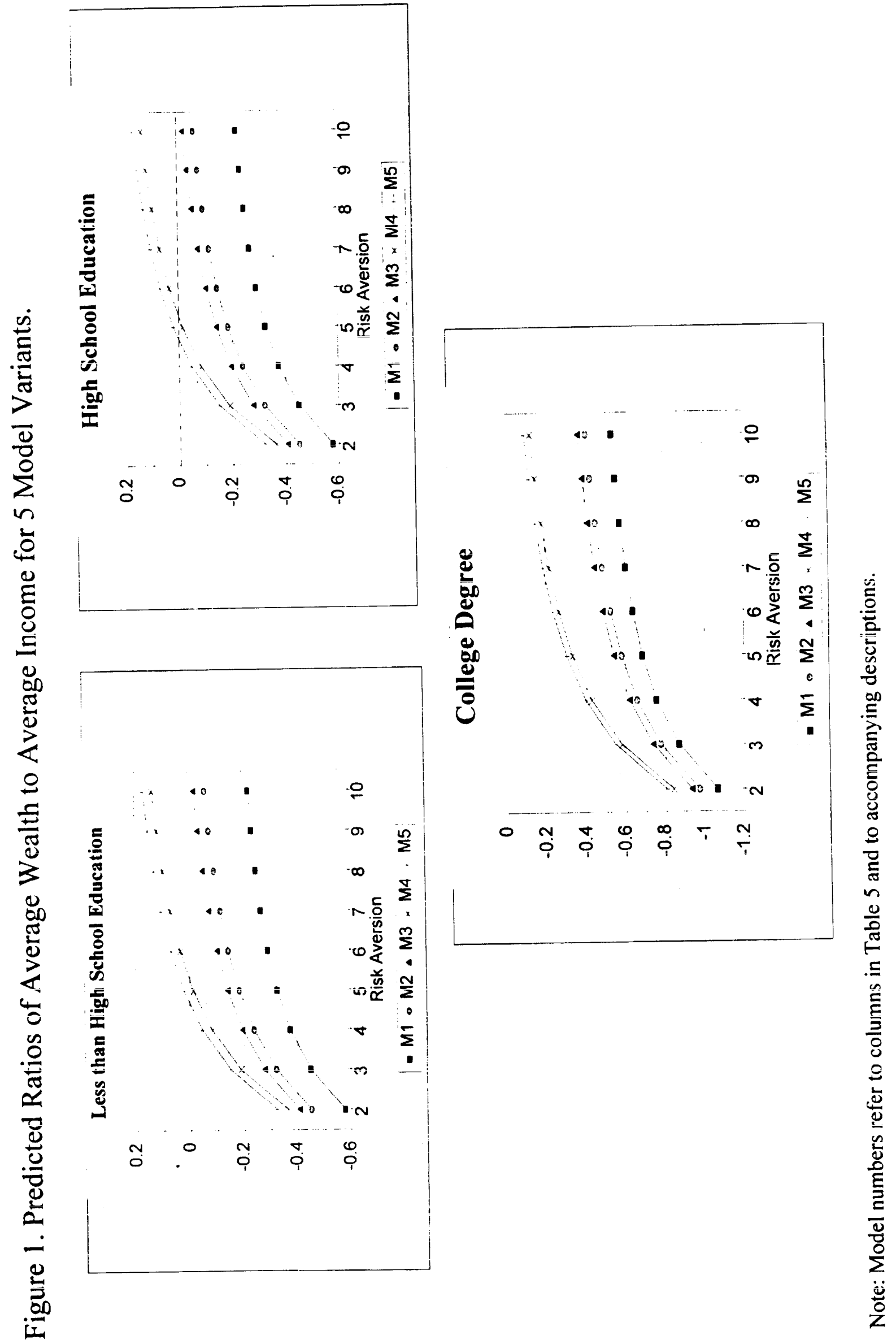




\section{ENDNOTES}

1. See, for example, White (1978), Kotlikoff and Summers (1981), Auerbach, Kotlikoff and Skinner (1983), Auerbach and Kotlikoff (1987), Hubbard and Judd (1987).

2. For example, Venti and Wise (1987); Bernheim and Scholz (1993).

3. Analytical results have been derived for utility functions with restrictive properties, such as the exponential which implies zero wealth elasticity of risky investment.

4. Guiso, Jappelli, and Terlizzesse (1992) find a small role for income variance, while more positive findings for precautionary saving are in Dardanoni (1991), and in Carroll and Samwick (1992). Guiso, Jappelli and Terlizzesse (1994) is the first paper we are aware of which tests portfolio predictions of shortrun precautionary models econometrically, with encouraging results. In a theoretical paper, Aiyagari (1994) argues that precautionary saving is smaller in general equilibrium, infinite horizon models.

5. According to the 1992 Survey of Consumer Finances, $90.9 \%$ of the population did not trade stocks in the course of the survey year and only $3.2 \%$ traded more than 4 times. Even among those in the population who still owned stocks at the time of the interview, $71.8 \%$ did not trade any stocks during the entire year. The corresponding figures for college-educated households are $80.1 \%, 7.4 \%$, and $63.5 \%$ respectively.

6. Our understanding of optimal precautionary portfolio allocation is fairly limited. Effects of background income risk on the demand for risky assets have been derived analytically in atemporal models by Pratt and Zeckhauser (1987), Kimball (1991, 1993), and Elmendorf and Kimball (1991). Pratt and Zeckhauser (1987) show that under certain conditions, if stockholding risk was undesirable in the absence of income risk, it will not be desirable in its presence. Kimball (1993) derives conditions under which income risk would limit the scale of stockholding. Elmendorf and Kimball (1991) show that the effects of income taxation on the demand for risky assets are ambiguous. A number of general equilibrium models specify asset supplies and focus on explaining asset returns and equity premia. Constantinides and Duffie (1992) explore the implications of persistent and heteroskedastic labor income shocks for asset pricing. Aiyagari and Gertler (1991) study asset returns, but also find that actual stockholding is too small relative to the amount of government debt needed to clear markets in a model with transactions costs, an infinite horizon, and a continuum of agents. Heaton and Lucas (1992) find that transactions costs and persistent income shocks raise the predicted equity premium. Weil (1990) shows that the representative agent consumptionbased model underpredicts the equity premium and overpredicts the riskless rate when income risk is ignored for many commonly used utility functions (excluding exponential utility).

7. See Haliassos (1994) for discussion and numerical illustrations of the implications of using deterministic instead of stochastic models to analyze long-run economic behavior.

8. For all education levels, little emphasis should be placed on the sizable stock holdings and financial net worth of those aged over 80 years. Although all respondents are weighted to match population statistics and these weights produce reliable estimates for broad aggregates, the high mean figures are largely the result of the disproportionate weight of a few especially wealthy households aged 80-85. 
9. Since capital gains are taxed at realization rather than accrual, introduction of capital gains taxation complicates the problem considerably, since we have to keep track of the time at which each stock was purchased. See Haliassos and Lyon (1994) for numerical solutions to a model incorporating capital gains taxation but no income risk.

10. The mean (received) inheritance by category was: $\$ 4038$ for LTHS; $\$ 10739$ for HS; $\$ 43884$ for COL.

11. While infinite-horizon models have interesting applications, concern with the utility of descendants (who also care about the utility of their offspring) effectively requires households to have information about how possibly unborn descendants feel or behave, and expectations about how their careers and future economic conditions will evolve. There is no obvious empirical counterpart to such well-informed dynasty members, especially since we are looking at households in their twenties and thirties.

12. This is higher than the mean value of $0.8 \%$ estimated by Mehra and Prescott (1985) and used for calibrating the riskless rate in the model. Compared to models which set the rate of time preference equal to the riskless rate, this lowers predicted wealth and makes it more difficult for the model to match the data (see below).

13. These first two moments have received considerable attention in the literature (e.g., on the equitypremium puzzle), and have been the focus of historical studies, such as Mehra and Prescott (1985) and Siegel (1992). If consensus on higher moments is established, these could be incorporated by considering more states of the world. Joint consideration of more than two asset return outcomes with more than two labor income outcomes raises the number of states considerably, and use of large-scale optimization methods becomes advisable. Optimization software such as GAMS or MATLAB could be helpful for smaller problems, but high-performance computing (including parallel processing) may be necessary for finer approximations to the range of possible outcomes.

14. The Mehra-Prescott mean annual stock returns and standard deviation for the period 1889-1978 are $6.98 \%$ and $16.54 \%$ respectively. The mean riskless rate was $0.80 \%$. The twenty-year "high" and "low" stock returns are 5.851241 and -0.14075 respectively. The corresponding dividend yields are 2.005997 and 0.849247 .

15. Some empirical findings on the importance of positive correlation ("business cycie risk") for the issue of whether to hold stocks are discussed in Haliassos and Bertaut (1995). Its combination with short sales constraints appears to have some explanatory power for the decision not to hold stocks.

16. Incomes under certainty are derived from age-education profiles in the 1992 SCF. Because of the small number of observations in each age-education cell, we divide the 60 years of data into twelve five-year ranges and compute average incomes for each range, using correct population weights. The representative household is then assumed to receive that level of income for each of the five years in the range. In the case of households with less than high school education, six ten-year ranges are used.

17. As can be inferred from Table 3, very small discrepancies do occur, because we use stochastic income draws for a large number of households (at least 10,000) to compute expected values and standard deviations of the income measure. 
18. When $X$ is lognormally distributed and $\ln X$ has mean $\mu$ and standard deviation $\sigma$, $E(X)=\exp \left(\mu+\frac{1}{2} \sigma^{2}\right)$ rather than $e^{\mu}$.

19. An analogous adjustment is used in Hubbard et. al. $(1994,1995)$ who focus on persistent shocks but abstract from transitory shocks.

20. Generally, we multiply the number of households in a particular category by an integer which will result in a figure close to 10000 . In removing unwanted effects of lognormal shocks on income means, we apply the same formula (10) to correct annual income levels. The sum of variances needed for correction in the first year is now given by $\rho^{2} \sigma_{u_{39}}^{2}+\sigma_{\epsilon}^{2}+\sigma_{v}^{2}$, where the first variance is the unconditional variance of persistent income shocks at age 39. The recursive formula now is: $\sigma_{u, t}^{2}=\sigma_{u, t-1}^{2}+\rho^{2(t-1)}\left[\left(\rho^{2}-1\right) \sigma_{u_{39}}^{2}+\sigma_{\epsilon}^{2}\right]$.

21. Analogous effects were found in the context of an expected-utility model with more detailed specification of interest, dividend, and capital gains taxation (Haliassos and Lyon, 1994). Whether such results hinge on the extent to which the government absorbs the resulting changes in portfolio income risk is a subject of ongoing research by Haliassos and Lyon.

22. In end-of-period models, households make choices of portfolios to hold over the second period after observing the realization of first-period income. Since only one household is considered in a representative agent framework, its realized first-period income is set at the per capita income for the education group, allowing no role for first-period income shocks and their persistence into the second period.

23. Concern about the size of accidental bequest as a result of premature death would be a mitigating factor.

24. Model predictions regarding the average wealth (stocks) to income ratio are very close to those on the ratio of averages, but empirical wealth (stock) to income ratios are very noisy in our data. Model predictions on ratios of medians virtually coincide with predictions on median ratios. 


\section{International Finance Discussion Papers}

IFDP

Number

Titles

Author(s)

1996

542 Precautionary Portfolio Behavior from a Life-Cycle Perspective

Carol C. Bertaut

Michael Haliassos

$541 \quad$ Using Options Prices to Infer PDF's for Asset Prices: An Application to Oil Prices During the Gulf Crisis

William R. Melick

Charles P. Thomas

540 Monetary Policy in the End-Game to Exchange-Rate Based Stabilizations: The Case of Mexico

Steven B. Kamin

John H. Rogers

Martin Uribe

539 Comparing the Welfare Costs and the Initial Dynamics of Altemative Temporary Stabilization Policies

538 Long Memory in Inflation Expectations: Evidence from International Financial Markets

Joseph E. Gagnon

537 Using Measures of Expectations to İdentify the Effects of a Monetary Policy Shock

Allan D. Brữñễ

Chan Huh

536 Regime Switching in the Dynamic Relationship between the Federal Funds Rate and Innovations in Nonborrowed Reserves

535 The Risks and Implications of External Financial Shocks: Lessons from Mexico

Edwin M. Truman

Jeffrey A. Frankel Currency Crashes in Emerging Markets: An Empirical Treatment

Andrew K. Rose

Charles Engel

Regional Patterns in the Law of One Price:

The Roles of Geography vs. Currencies

John H. Rogers

1995

532 Aggregate Productivity and the Productivity of Aggregates

Susanto Basu John G. Fernald

531 A Century of Trade Elasticities for Canada, Japan, and the United States

Jaime Marquez

$530 \quad$ Modelling Inflation in Australia

Gordon de Brouwer Neil R. Ericsson

Please address requests for copies to International Finance Discussion Papers, Division of International Finance, Stop 24, Board of Governors of the Federal Reserve System, Washington, DC 20551. 
IFDP

Number

\section{Author(s)}

1995

529

Hyperinflation and Stabilisation: Cagan Revisited

528 On the Inverse of the Covariance Matrix in Portfolio Analysis

527 International Comparisons of the Levels of Unit Labor Costs in Manufacturing

526 Uncertainty, Instrument Choice, and the Uniqueness of Nash Equilibrium: Microeconomic and

Macroeconomic Examples

525 Targeting Inflation in the 1990s: Recent Challenges

524 Economic Development and Intergenerational Economic Mobility

523 Human Capital Accumulation, Fertility and Growth: A Re-Analysis

522 Excess Returns and Risk at the Long End of the Treasury Market: An EGARCH-M Approach

521 The Money Transmission Mechanism in Mexico

520 When is Monetary Policy Effective?

519 Central Bank Independence, Inflation and Growth in Transition Economies

518 Alternative Approaches to Real Exchange Rates and Real Interest Rates: Three Up and Three Down

517 Product markêt competition and the impact of price uncertainty on investment: some evidence from U.S. manufacturing industries

$516 \quad$ Block Distributed Methods for Solving Multi-country Econometric Models

515 Supply-side sources of inflation: evidence from OECD countries
Marcus Miller

Lei Zhang

Guy V.G. Stevens

Peter Hooper

Elizabeth Vrankovich

Dale W. Henderson

Ning S. Zhu

Richard T. Freeman Jonathan L. Willis

Murat F. Iyigun

Murat F. Iyigun

Allan D. Brunner

David P. Simon

Martina Copelman

Alejandro $\mathrm{M}$. Werner

John Ammer

Allan D. Brunner

Prakash Loungani

Nathan Sheets

Hali J. Edison

William R. Melick

Vivek Ghosal

Prakash Loungani

Jon Faust

Ralph Tryon

Prakash Loungani

Phillip Swagel 